\title{
Effects of ephemeral circulation on recruitment and connectivity of nearshore fish populations spanning Southern and Baja California
}

\author{
Kimberly A. Selkoe ${ }^{1,3, *}$, Augustus Vogel $^{2}$, Steven D. Gaines ${ }^{1}$ \\ ${ }^{1}$ Department of Ecology, Evolution and Marine Biology, University of California, Santa Barbara, California 93106, USA \\ ${ }^{2}$ Department of Biology, University of Southern California, Los Angeles, California 90089, USA
}

${ }^{3}$ Present address: Hawai'i Institute of Marine Biology, PO Box 1346, Kaneohe, Hawaii 96744, USA

\begin{abstract}
The California sheephead Semicossyphus pulcher and the kelp bass Paralabrax clathratus are members of a suite of nearshore reef species that have subtropical taxonomic affiliations and important fisheries in the Southern California Bight (SCB). This suite shows high interannual fluctuation in recruitment success in the $\mathrm{SCB}$, with no known cause. One hypothesis gaining mention in management literature is the idea that recruitment booms in the SCB originate from larvae swept poleward from Mexico during El Niño flow-reversal events. If true, SCB stocks may be reliant on Mexican sources. We used 3 diverse sources of data to investigate the likelihood of El Niño-driven recruitment success and connectivity for $S$. pulcher and P. clathratus. Time series of larval abundance revealed that neither species shows synchrony with El Niño Southern Oscillation (ENSO) cycles that would suggest influx of Mexican larvae during El Niño flow reversals. P. clathratus age structure data show that recruitment strength is unrelated to ENSO cycles but correlates to spring sea surface temperature in the $\mathrm{SCB}$, indicating that local environmental factors drive interannual variation in local production. Genetic analyses of 14 populations of P. clathratus with 7 microsatellite loci revealed distinct patterns of genetic structure in the SCB and Baja California that reflect localized connectivity patterns and contradict patterns that would be expected if dispersal primarily occurred during El Niño flow reversals. While these results support the importance of protecting local sources in the $\mathrm{SCB}$, continued study of dispersal and recruitment at large scales will help characterize the causes of interannual variation and the exact scale of cross-border connectivity.
\end{abstract}

KEY WORDS: Baja California - El Niño - ENSO - Fish recruitment · Kelp bass · Paralabrax · Semicossyphus pulcher $\cdot$ Southern California Bight

\section{INTRODUCTION}

In many areas of the world, international borders cut across continuous habitats and ecological communities. These areas are often managed independently despite the possibility that connectivity between them may be extensive for many species. The adjacent nearshore marine ecosystems of Southern California, USA, and Baja California, Mexico, are a prime example of this scenario. In Baja California, small-scale artisanal fisheries harvest nearshore rocky reef and kelp forest fauna and represent a considerable fraction of the economic value of Mexico's fisheries (RosalesCasian \& Gonzalez-Camacho 2003). Across the international border, the same species support recreational and commercial fisheries in the Southern California Bight (SCB). Roughly 3 million recreational fishing trips targeting nearshore fishes and invertebrates are made yearly in Southern California, generating $\geq \$ 300$ million $\mathrm{yr}^{-1}$ in revenue (Thomson \& Crooke 1991). Species shared between the Mexican and US fisheries include rockfishes in the genus Sebastes, 
California sheephead, ocean whitefish, kelp and sand basses, California halibut, urchins, and California spiny lobster. Because most of these species have planktonic larvae capable of dispersing tens to hundreds of kilometers before settlement, it is possible that population connectivity across the border is extensive and vital for the continued sustainability of local fisheries in one or both countries.

California's Marine Life Management Act (MLMA) acknowledges potential reliance on Mexican populations for contributions to stock replenishment in its MLMA Master Plan, which explains that 'warm waters that flow north in an El Niño carry the larvae of sheephead and lobster from the heart of their geographic range in Mexico into the waters off California' (www.dfg.ca.gov/marine/masterplan). The 2004 National Marine Fisheries Management Plan for the California sheephead Semicossyphus pulcher likewise acknowledges that 'there could be cross-border movement ... influenced by environmental events such as El Niño' (Methot et al. 2004). If the transport of young from natal sites in Mexico plays an important role in the dynamics of US populations, the need for close international coordination in management of these fisheries would be critical. However, despite repeated statements of this hypothesis in both scientific and management documents, its validity remains largely untested.
As mentioned in the quotes above, the key mechanism for allowing significant connectivity is El Niñodriven flow reversals. Without El Niño conditions, the basic patterns of regional coastal circulation during summer months (June to September, when larvae of most nearshore reef species disperse) suggest low connectivity across the international border. In these 'normal' summers, a large cyclonic eddy stretches from just south of the international border to the Santa Barbara Channel, encapsulating the SCB into what may be a largely closed system (Hickey 1998) (Fig. 1a). The SCB is divided from northern Baja California by an eastward flowing arm of the California Current (CC) that impinges on the coast north of Ensenada (Fig. 1a), producing divergent flow and a boundary in temperature and productivity called the Ensenada front (Haury et al. 1993, Perez-Brunius et al. 2006). The front has been characterized as a faunal boundary for some pelagic taxa (reviewed in Haury et al. 1993). Along the coast of northern Baja California, linear equatorward flow dominates, further enhancing the obstacle to poleward transport of larvae from Baja California to the SCB (Fig. 1a).

The rationale for a potential dependency on Mexican source populations for California stocks arises from the very different basic circulation pattern that occurs ephemerally under El Niño conditions. In strong
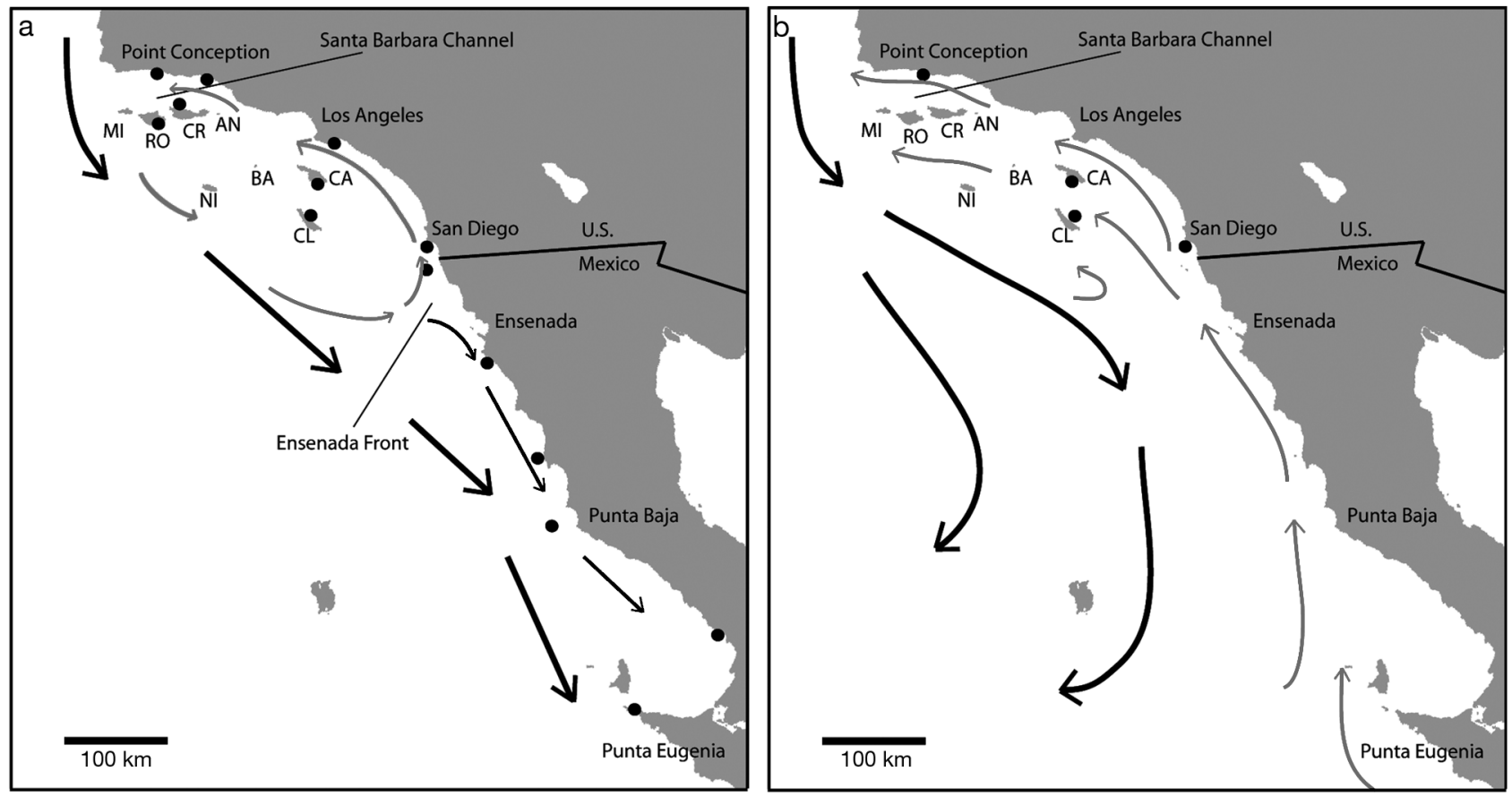

Fig. 1. Mean large-scale flow along the study region, reproduced from Hickey (1998) and Durazo \& Baumgartner (2002). Black arrows: California Current. (a) 'Normal' (non-El Niño) summer flow conditions. Southern California Eddy: 5 counterclockwise curved arrows; : Paralabrax clathratus genetic sampling sites. (b) El Niño conditions; gray arrows show a warm-water poleward current. @: P. clathratus age structure sampling sites. Islands: San Miguel (MI), Santa Rosa (RO), Santa Cruz (CR), Anacapa (AN), Santa Barbara (BA), San Nicholas (NI), Santa Catalina (CA), San Clemente (CL) 
El Niño events, a warm-water poleward current runs inshore up the Pacific coast of Baja California, through the SCB and occasionally as far north as Oregon and Washington, pushing the equatorward flowing CC far offshore (Durazo \& Baumgartner 2002, Perez-Brunius et al. 2006) (Fig. 1b). Documented flow reversals in surface waters are associated only with El Niño conditions (Chelton 1981). Since many reef species are believed to have recruitment peaks in the SCB following El Niño (Johnson 1960, Cowen 1985, Pringle 1986, McGowen 1993, Carr 1994, Pondella \& Stephens 1994, Lenarz et al. 1995, Moser et al. 2001), poleward larval transport across the US-Mexican border during El Niño has emerged as a hypothesis that is being incorporated into management plans. Moser et al. (2001) presented support for this hypothesis by examining the exact timing of the appearance of a large pulse of sheephead larvae in the southern SCB at the end of the 1998 El Niño. They linked the sheephead pulse to the poleward transport of an unusually large mass of warm water from Mexico into the SCB that was documented prior to the appearance of the sheephead (Moser et al. 2001).

Species with El Niño-associated recruitment also have other traits that suggest local production in the SCB may be low or unreliable, making it more likely that input from Mexico during El Niño may be crucial to SCB stocks. They have high interannual variation in recruitment success at sites in the SCB, with frequent years of near-total recruitment failure (Cowen 1985). Some have been demonstrated to be recruitment-limited (sheephead, Cowen 1985; kelp bass, Carr 1994). They also tend to share subtropical taxonomic affiliations, such that the majority of their range is in Mexican waters and abundance attenuates near Point Conception. Most have pelagic larval durations of 1 to 2 mo. Some of the more abundant and/or economically important examples of this suite of species are the California sheephead Semicossyphus pulcher, kelp bass Paralabrax clathratus, barred sand bass $P$. nebulifer, opaleye Girella nigricans, and garibaldi Hypsypops rubicundus.

Success of local larval production in the SCB for these subtropical species might be compromised in parts of the SCB due to temperature minima or other physiological constraints on gamete production or larval survival (Oda et al. 1993), or larvae might simply be advected out of the local area (Watson et al. 1999). Even if recruits are locally produced in the SCB annually — as seems evident at least for the more abundant species like sheephead and kelp bass (Watson et al. 2002) - the rate of local reproduction might be swamped over the long term by episodic influxes of larvae from the more abundant and extensive populations in Baja California during El Niño flow-reversal events. This scenario, if true, has substantial implica- tions for our basic understanding of the ecological dynamics of kelp forest and rocky-reef communities of the SCB and the impacts of future climate change, shifts in El Niño Southern Oscillation (ENSO) cycles, and economic changes in Mexico on the populations and fisheries of these species.

Importantly, however, increases in recruitment in the SCB following El Niño conditions could alternatively be explained by enhanced local reproduction in the SCB due to associated environmental changes rather than through enhanced immigration (e.g. warmer conditions support greater larval production and/or larval survival from SCB populations). Furthermore, we are unaware of any rigorous analyses of the actual correlation between interannual patterns of recruitment for these species and ENSO cycles. Much of the presumed association has been based on observations associated with single events (e.g. the 1982-83 El Niño: Cowen 1985; Stephens \& Pondella 2002), which leaves open the question of whether a correlation between recruitment and ENSO cycles would be confirmed for longer recruitment time series.

These species clearly have strong interannual fluctuation in recruitment in the $\mathrm{SCB}$, and understanding the cause is important to their fisheries management. In the present paper we focus on the idea that this fluctuation is related to ENSO and examine support for the hypotheses that recruitment booms are linked to (1) the influx of Mexican larvae via poleward flow reversals or (2) increased local production when local sea surface temperatures (SST) are higher than average. The definitive way to understand the extent to which Mexican populations contribute to SCB populations would be to identify what proportion of individuals found in the SCB has natal origins in Mexico versus California. Currently, such definitive evidence does not exist at the required scales or with sufficient power to determine the sources of recruits. However, we assembled a diverse body of data on spatial and temporal patterns of larval abundance, age structure and genetic structure with which to address links between ENSO and recruitment booms and the likelihood of substantial contribution of long-distance dispersal from Mexico to Californian populations.

\section{MATERIALS AND METHODS}

The 2 species of focus in this analysis, the California sheephead Semicossyphus pulcher and the kelp bass Paralabrax clathratus, show very similar patterns of larval dynamics. Both taxa peak at the most inshore stations of the California Cooperative Oceanic Fisheries Investigations (CalCOFI) grid $(<50 \mathrm{~km}$ from shore), suggesting that most larvae do not travel far offshore during their pelagic phases. In addition, the 
distributions of Paralabrax spp. (a majority kelp bass and minority barred and spotted sand bass) and sheephead larvae were spatially correlated at a small scale in tows made within the inshore region from 1982 to 1984, suggesting they experience similar physical forces (McGowen 1993). Other subtropical species identified in CalCOFI tows that share both the inshore bias and lack of positive tows north of Point Conception are the rock wrasse Halichoeres semicinctus, garibaldi Hypsypops rubiscens and opaleye Girella nigricans (McGowen 1993). These data suggest that these subtropical species indeed form a suite with respect to the environmental forces impacting their broad-scale connectivity. Thus, similarities in larval life history and spatio-temporal larval patterns allow some generalization of data presented here to the others in this subtropical suite.

Interannual patterns of larval abundance. CalCOFI surveys have produced a long-term time series of larval abundance for Semicossyphus pulcher larvae and Paralabrax spp. larvae from 1951 to 2004 (www.calcofi.org). Following Moser et al. (2002), we estimated larval abundance as the proportion of positive CalCOFI oblique tows (i.e. tows capturing $\geq 1$ larva of the focal taxon) to get a relative estimate of larval abundance. Data were filtered to include only tow stations within the SCB (east of Stn 40 at line 93 and Stn 55 at line 80 ), so as to exclude larvae that are likely lost to the system, and excluded winter months when no larvae of these species are found (December to April). We evaluated whether peaks in larval abundance coincided with El Niño conditions, which would support the possibility that they are caused by transport from Mexico. Strength of El Niño was estimated by averages of monthly values of a multivariate ENSO index (MEI) that measures the departure from mean conditions (positive values represent El Niño conditions; available from K. Wolter at www.cdc.noaa.gov/people/ klaus.wolter/MEI/table.html). Only months during the likely spawning window, May through September, were included (Moser et al. 2002). As yearly averages of ENSO have little serial autocorrelation, we used ordinary least-squares regression to test for a positive relationship between larval abundance and the strength of El Niño. We also repeated the correlation using a more local indicator of ENSO, monthly mean upwelling indices for $30^{\circ} \mathrm{N}$ and $33^{\circ} \mathrm{N}$ also averaged for spawning months (available at www.pfeg.noaa.gov).

Interannual patterns of recruitment. We looked for further evidence that the peaks in recruitment correlated with El Niño conditions using data on the strength of recruitment calculated from age structure data for 1500 Paralabrax clathratus collected from 2001 to 2003 at 4 sites in the SCB (Fig. 1b). All fish were captured with hook and line and aged with their otoliths; age structure data were transformed into a recruitment index by accounting for natural mortality (A. Vogel, C. Burrell, S. Edmands, D. Keifer unpubl.). Briefly, collection sites were pooled into 2 groups, based on an obvious difference in fishing pressure $(37.3 \pm 15.4 \%$ of the samples from the 'lightly fished' sites and $3.0 \pm 1.5 \%$ from the 'heavily fished' sites were born before 1991). Data from the 2 groups were $\log _{10}$-transformed before calculating best-fit linear regression lines. We took the inverse logs of the $y$-values from the 2 regression lines in order to create exponential curves that covered the years 1969 to 2005. All year points were then divided by the 2005 values, which standardized the curves to have a maximum of 1 . Mortality for each year was considered to be the ratio of successive steps in these survivorship curves.

Relative recruitment strength for each year (determined with otolith scores) was estimated by calculating survivorship through successive mortality steps. Here we only include the year classes that recruited between 1985 and 1997 because these are the most densely sampled year classes. Finally, these recruitment scores were normalized. We then asked whether recruitment strength (averaged across the 4 sites) correlated with ENSO patterns, indicating that recruitment peaks are possibly related to flow-reversal events allowing transport from Mexico. We also tested whether recruitment correlated with spring SST in the SCB (March to May, averaged), indicating that local environmental conditions may drive reproductive output of SCB populations. Temperature data used were monthly means of in situ measurements averaged across the same 4 collection sites, downloaded from the Southern California Coastal Observing System (www. sccoos.org). Although SST can be somewhat correlated with ENSO, the temperature used in the ENSO index is taken from the tropical Pacific and is only 1 of the 6 variables used to calculate the ENSO index.

Spatial patterns of genetic structure. Genetic structuring for these species was expected to be low given their long larval durations (1 to $2 \mathrm{mo}$ ) and large population sizes. Nevertheless, examining the relative levels and patterns of structure in the SCB and in Mexico may help in determining the influence of ephemeral El Niño flow reversals on larval sources in the SCB. The following 3 paragraphs outline, several hypotheses about patterns of gene flow based on the current patterns described in the Introduction and shown in Fig. 1.

In northern Baja California, currents run linearly along the coast, during both normal and El Niño conditions, so gene flow among Mexican sites is expected to fit a stepping-stone model, in which dispersal occurs primarily between adjacent populations. Thus, regardless of whether gene flow within Baja occurs only during normal years, only during El Niño conditions or 
both, we hypothesize that sites within Baja display a genetic pattern of isolation-by-distance, in which genetic differentiation increases linearly with geographic distance between populations. Although the currents in both conditions are asymmetrical (normal: equatorward, El Niño: poleward), isolation by distance occurs despite dispersal asymmetry (Rousset 2004).

In the SCB, the different current patterns during El Niño and normal summer conditions should result in contrasting associated gene flow patterns. Under the hypothesis that population replenishment in the SCB largely occurs from the influx of Mexican larvae via poleward flow during El Niño, local production is minimal, and immigrants to all SCB populations come from a large, homogeneous pool of larvae from Mexico because larvae from diverse locations in Mexico become mixed during transport to the SCB and are distributed widely to areas within the SCB. Thus, all populations receive the same genetic input, so we hypothesize that there is no genetic structure among the SCB sites.

In contrast, under the hypothesis that recruitment in the SCB primarily occurs during normal conditions, local production results in a fraction of self-recruitment and some interpopulation exchange of immigrants within the SCB, with little or no input from Mexico. Because currents within the Southern California Eddy are slow, larval retention and thus self-recruitment should be relatively high, allowing buildup of genetic structure. The circuitous currents should allow larval exchange between nonadjacent areas, preventing isolation by distance. Therefore, this hypothesis predicts that genetic differentiation among sites in the SCB should be fairly high, but lack a pattern as compared to the structuring within Baja, where currents along the coast are faster but linear. This hypothesis also predicts that genetic structure should exist between the SCB and Mexico because the Ensenada front might dampen most international gene flow.

To test the above hypotheses, we analyzed the Paralabrax clathratus population genetic structure from 14 population samples taken between Punta Eugenia and Point Conception between 2001 and 2004 (Fig. 1a) with 7 microsatellite loci (sampling methods, loci, and DNA methods identical to those in Selkoe et al. 2006). All loci passed tests for Hardy-Weinberg equilibrium, linkage equilibrium, and neutrality (Selkoe et al. 2005, 2006). A measure of genetic differentiation, $F_{\mathrm{ST}}$, was estimated with Weir \& Cockerham's (1984) estimator for 3 sets of data: a global value averaged over all populations, values averaged separately within each region (9 sites in the SCB and 5 sites in northern Baja California), and all pairwise comparisons among the 14 sites. Confidence intervals (CI) for the regional $F_{\mathrm{ST}}$ values were generated with GENETIX (Belkhir et al. 1998) to determine whether the populations in the SCB show a lesser degree of genetic structuring than those in northern Baja California (supporting the contribution of Mexican sources) or an equal or greater degree of genetic structuring (supporting overwhelming dominance of local reproduction). Hedrick's (2005) correction procedure was used to adjust the global $F_{\mathrm{ST}}$ value because the high allelic diversity and high population sizes of kelp bass depress $F_{\mathrm{ST}}$ values (Kalinowski 2002). The uncorrected pairwise $F_{\mathrm{ST}}$ values were used to determine whether pairs of populations within the SCB and within Baja California exhibited distinct patterns of genetic structure. Values were plotted by pairwise distance to evaluate isolation by distance and significance was tested with a Mantel test (Rousset 1997).

\section{RESULTS}

\section{Interannual larval abundance patterns}

The CalCOFI larval tow time series showed that Semicossyphus pulcher larval abundance falls to zero in many years and Paralabrax spp. larval abundance drops significantly, consistent with wide interannual

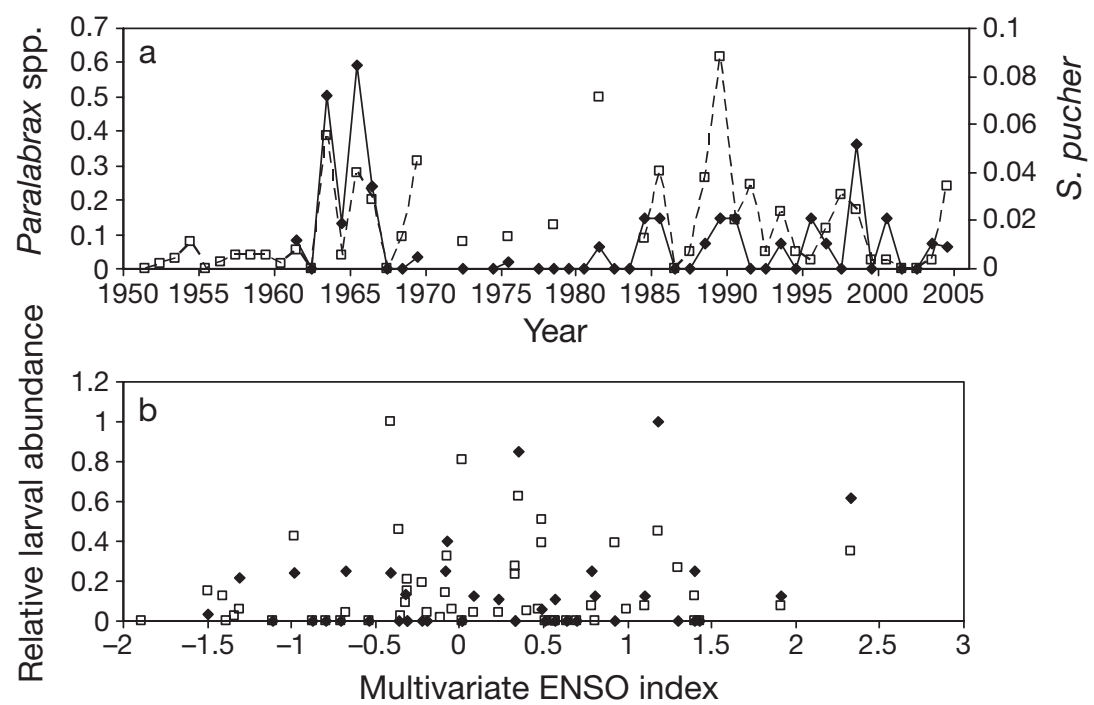

Fig. 2. Semicossyphus pulcher $(\diamond)$ and Paralabrax spp. ( $\square$ ). (a) Relative abundance time series of larvae in the Southern California Bight, as \% positive tows $\mathrm{yr}^{-1}$. Between 1969 and 1984, sampling occurred every 3rd yr. (b) Correlations of larval abundance with multivariate El Niño Southern Oscillation (ENSO) index, indicating strength of El Niño (positive values) and La Niña conditions (negative values), using months during spawning period only 
variability in recruitment, including years of widespread failure (Fig. 2a). The annual larval abundance data for the 2 taxa were positively correlated for the duration of the time series $\left(\mathrm{r}^{2}=0.21, \mathrm{p}=0.02\right)$. The ENSO time series showed many strong El Niño periods during spawning months over those years, but the larval data showed no relationship to ENSO cycles as measured by the MEI (S. pulcher: $\mathrm{r}^{2}=0.01, \mathrm{p}=0.92$; Paralabrax spp.: $\mathrm{r}^{2}=0.01, \mathrm{p}=0.97$ ) (Fig. $2 \mathrm{~b}$ ), or the local upwelling indices (data not shown). When adjusted larval count data were used instead of percent positive tows, the results were similar because the 2 metrics are well correlated themselves (data not shown).

\section{Age structure data}

The annual strength of recruitment derived from the Paralabrax clathratus age structure data showed a range of values between 1985 and 1997, and there were $\geq 4$ strong El Niño yr during this period (Fig. 3a). In fact, 1997 and 1987 showed the highest summer MEI values for the entire 1950 to 2004 time series. Strength of recruitment showed no correlation with the strength of El Niño but did show a negative correlation with spring SST $\left(r^{2}=0.33, p=0.035\right)$ (Fig. 3). No correlation with summer SST was found (data not shown).

\section{Spatial patterns of genetic structure}

Descriptive statistics for the 14 sites from the analysis of 7 microsatellite loci are provided in Table 1. Calculated across all 14 sites, global $F_{\mathrm{ST}}=0.001$, similar to Paralabrax clathratus allozyme results in Waples \& Rosenblatt (1987). Unlike in that study, in our study the value was statistically $>0$ because of increased power $(p=0.03)$. Corrected for the high polymorphism of the loci according to Hedrick (2005), $F_{\mathrm{ST}}=$ 0.028 , indicating substantial genetic structuring. Structure in the SCB was slightly higher than in Baja California, instead of lower as would be expected with substantial Mexican input during El Niño flow reversals. For the $9 \mathrm{SCB}$ sites, uncorrected $F_{\mathrm{ST}}=0.0013(95 \%$ CI: 0.0003 to 0.0023 ) and was significantly $>0$, whereas for the Mexican subset of sites, $F_{\mathrm{ST}}=0.0009(95 \% \mathrm{CI}$ : -0.0008 to 0.0033 ) and was not statistically different from zero. However, the $2 F_{\text {ST }}$ values were not significantly different from each other.

Pairwise $F_{\mathrm{ST}}$ values varied among site

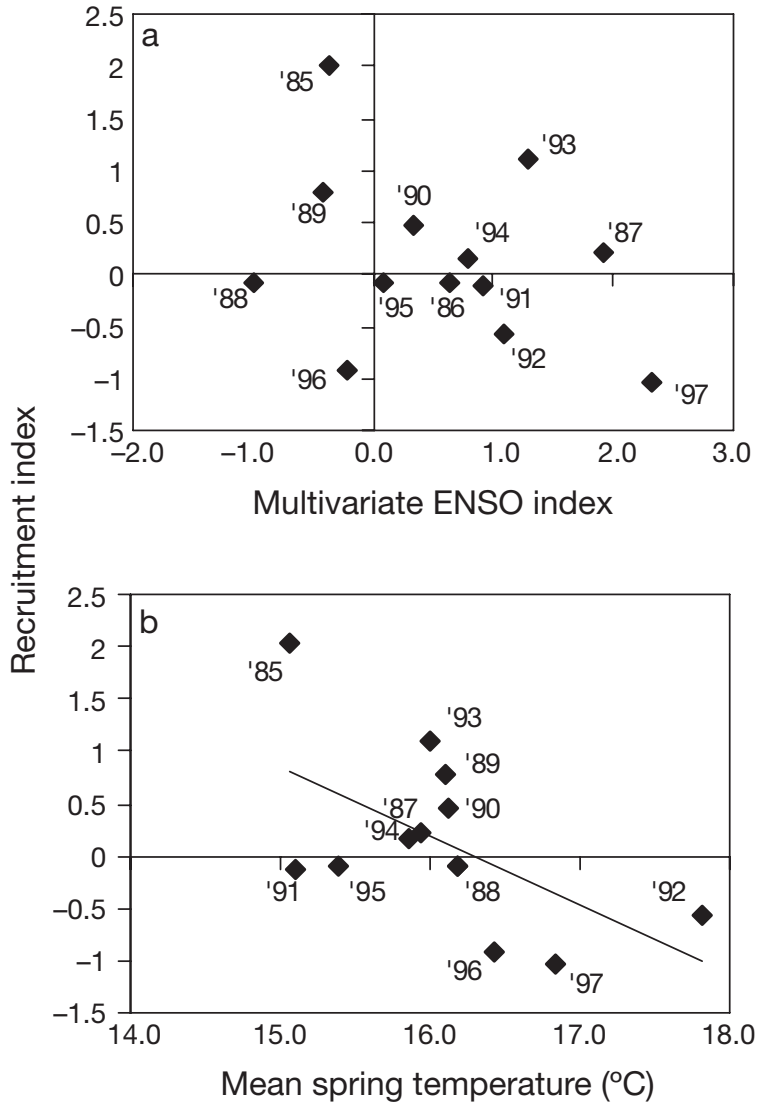

Fig. 3. Paralabrax clathratus. Correlational plots for the 1985-97 annual recruitment index, back-calculated from age structure data. (a) Recruitment strength is uncorrelated with multivariate El Niño Southern Oscillation (ENSO) index during spawning period (April to October). (b) Recruitment strength correlates with mean spring sea surface temperature (April to June) $\left(\mathrm{r}^{2}=\right.$ $0.33, \mathrm{p}=0.035)$. Yr indicated next to data points

Table 1. Genetic characteristics of all sites. SCB, Southern California Bight; $\mathrm{n}$, sample size; $H_{0}$, observed heterozygosity; $\mathrm{A}$, mean rarefied number of alleles per locus; $F_{\mathrm{IS}}$, inbreeding coefficient

\begin{tabular}{|llcrrrr|}
\hline Group & Location & Latitude $\left({ }^{\circ} \mathrm{N}\right)$ & $\mathrm{n}$ & $H_{\mathrm{o}}$ & $\mathrm{A}$ & \multicolumn{1}{c|}{$F_{\mathrm{IS}}$} \\
\hline SCB & Naples Reef & 34.42 & 104 & 0.72 & 13.5 & -0.018 \\
SCB & Carpinteria & 34.40 & 59 & 0.75 & 13.5 & -0.013 \\
SCB & Santa Rosa Is. & 34.05 & 43 & 0.73 & 12.3 & -0.023 \\
SCB & Santa Cruz Is. & 33.92 & 76 & 0.73 & 13.6 & 0.021 \\
SCB & Los Angeles & 33.79 & 124 & 0.73 & 13.1 & 0.002 \\
SCB & Catalina Is. & 33.42 & 43 & 0.74 & 13.4 & 0.013 \\
SCB & San Clemente Is. & 32.89 & 83 & 0.74 & 13.5 & 0.022 \\
SCB & San Diego & 32.66 & 84 & 0.72 & 13.3 & 0.007 \\
SCB & Islas Coronados & 32.44 & 71 & 0.71 & 13.5 & 0.004 \\
Mexico & Eréndira & 31.30 & 66 & 0.72 & 12.7 & -0.003 \\
Mexico & San Quintín & 30.48 & 71 & 0.73 & 12.7 & 0.048 \\
Mexico & Punta Baja & 29.79 & 53 & 0.73 & 13.6 & 0.014 \\
Mexico & Santa Rosalillita & 28.67 & 72 & 0.74 & 13.6 & 0.003 \\
Mexico & Punta Eugenia & 27.87 & 92 & 0.74 & 13.7 & 0.006 \\
\hline
\end{tabular}



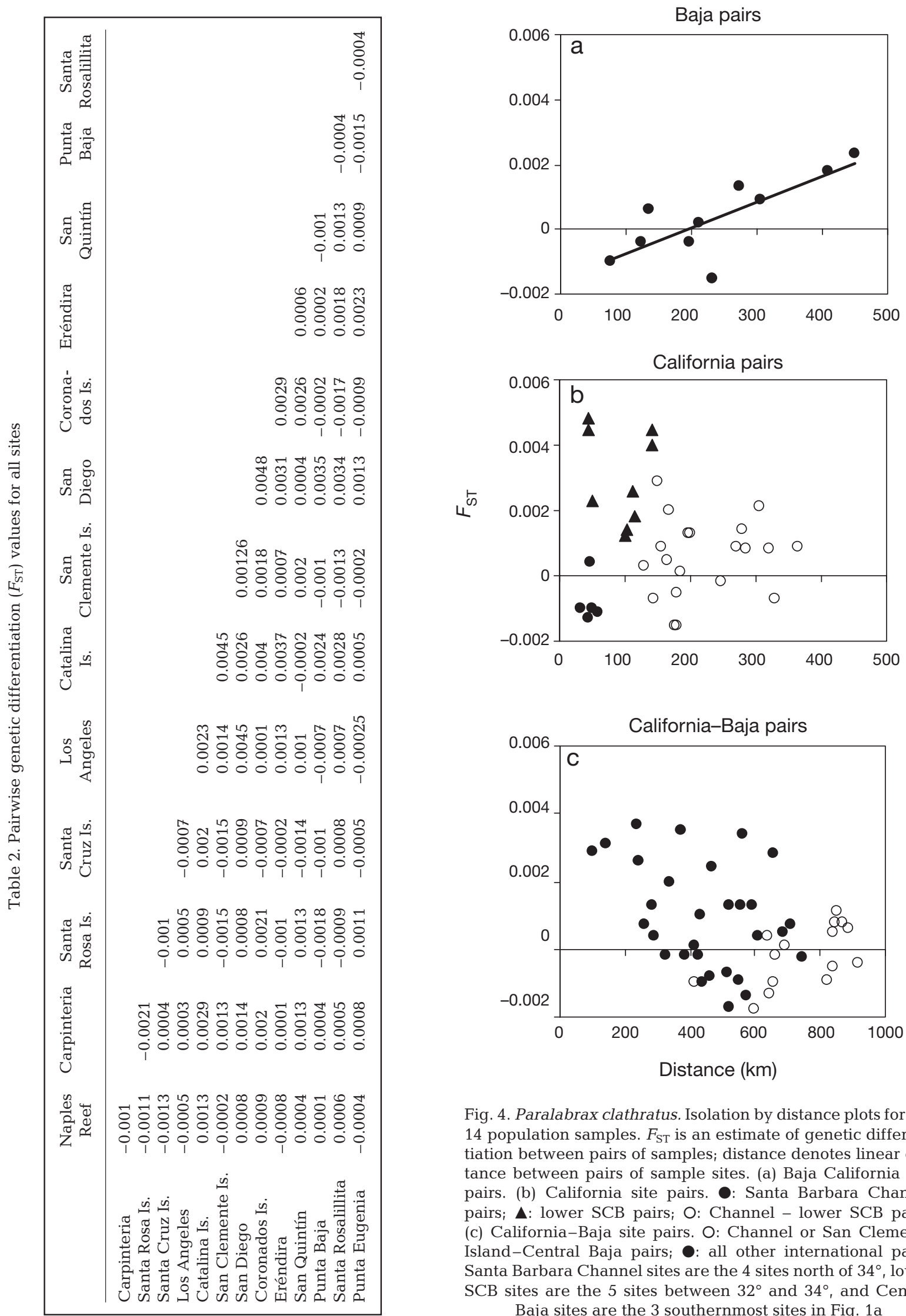

Fig. 4. Paralabrax clathratus. Isolation by distance plots for the 14 population samples. $F_{\mathrm{ST}}$ is an estimate of genetic differentiation between pairs of samples; distance denotes linear distance between pairs of sample sites. (a) Baja California site pairs. (b) California site pairs. @: Santa Barbara Channel pairs; $\Delta$ : lower SCB pairs; O: Channel - lower SCB pairs. (c) California-Baja site pairs. O: Channel or San Clemente Island-Central Baja pairs; - all other international pairs. Santa Barbara Channel sites are the 4 sites north of $34^{\circ}$, lower SCB sites are the 5 sites between $32^{\circ}$ and $34^{\circ}$, and Central Baja sites are the 3 southernmost sites in Fig. 1a 
pairs (Table 2). As expected, the Mexican populations revealed a linear isolation-by-distance relationship that typifies stepping-stone dispersal (Mantel $\mathrm{p}=0.01$; Fig. 4a), while SCB populations did not. Pairwise $F_{\mathrm{ST}}$ values for sites within the SCB showed multiple values that exceeded the maximum for the Baja California sites (Fig. 4b), and this relatively greater genetic differentiation of populations in the SCB compared to Mexico contradicts expectations under the hypothesis that the SCB is supplied by a homogeneous Mexican larval pool. Instead, the higher structuring suggests more localized dispersal, at least for the lower SCB; sites within the Santa Barbara Channel are genetically homogeneous (Fig. 4b). Pairwise $F_{\mathrm{ST}}$ between sites spanning the international border also showed many of the highest values (Fig. 4c), indicating an accumulation of genetic differentiation between SCB sites and Mexican sites that is inconsistent with larval supply from Mexico. However, international pairs farther from the border showed less genetic structure (Fig. 4c); this similarity is largely driven by the Santa Barbara Channel sites, which also showed high similarity to sites within the SCB (Fig. 4b), but is also true for San Clemente Island.

\section{DISCUSSION}

The present study combined diverse lines of evidence to evaluate whether large interannual fluctuation in recruitment is due to periodic infusions of larvae from Mexican sources during El Niño flow-reversal events. Taken together, the analyses provide no support for significant contribution of Mexican sources and several lines of evidence that contradict it. First, peaks in larval abundance and recruitment in the SCB showed no link to El Niño conditions and hence no link to poleward transport from Mexican sources. Second, the degree of genetic differentiation in the SCB was not reduced or absent relative to Baja California as would be predicted if recruitment partially stemmed from influxes of Mexican larvae. Instead, there tended to be larger pairwise $F_{\mathrm{ST}}$ values in the SCB and along the division between the regions. Although the degree of genetic structuring in kelp bass was low, this is expected, due to the large population sizes of the species dampening the rate of genetic drift and the high heterozygosities of the microsatellite loci, and cannot be assumed to reflect extensive dispersal (Kalinowski 2002). The consistency of the multiple lines of evidence adds strength to the analysis despite the limitations of any single data set.

The strength of Paralabrax clathratus recruitment over 13 yr correlated with spring SST instead of ENSO, indicating that local processes are more likely than large-scale transport mechanisms to cause the high interannual variation in recruitment. The negative correlation with spring SST may reflect the importance of food supply on gametogenesis (Love et al. 2002). Several studies have demonstrated a correlation between primary productivity during the period prior to reproduction and the fecundity, egg quality, and recruitment of rockfishes (Ventresca et al. 1995, Tolimieri \& Levin 2005). Although spawning occurs throughout the summer in kelp bass, oocyte maturation and spermatocyte production begins in April (Smith \& Young 1966), and there may be a need to boost fat reserves during the spring. Another study of recruitment strength in barred sand bass P. maculatofasciatus from 1978 to 1992 showed peak years for recruitment strength similar to our data (1984 to 1985 and 1990 to 1991) and also showed a positive relationship to SST, but to summer (June to September) instead of spring averages (Allen et al. 1995). Both data sets also showed considerable among-site variability in patterns, indicating that local environmental or ecological factors may be more important for predicting recruitment strength than regional phenomena.

Cowen's (1985) seminal work on interannual variability in sheephead recruitment is the most often cited source of support for the importance of Mexican sources for the SCB (e.g. Moser et al. 2001). Cowen (1985) observed that Semicossyphus pulcher recruitment at San Nicholas Island boomed in 1983, an El Niño year, after 8 yr of low recruitment, including 3 yr of total failure. A similar recruitment peak in 1983 for Paralabrax spp. is evident in nearshore tows taken from 1978 to 1984 (Stephens \& Pondella 2002). Cowen (1985) showed that 2 sites in Baja California had the opposite pattern: high recruitment except for recruitment failure in 1983. This temporal mismatch in recruitment has sometimes been interpreted as evidence for long-distance advection of Mexican larvae into California (e.g. Lenarz et al. 1995, Methot et al. 2004, MLMA Master Plan [www.dfg.ca.gov/marine/ masterplan]). Importantly, Cowen (1985) never explicitly argued that San Nicholas' source populations in 1983 were in Baja California, instead mentioning 'the mainland, San Clemente and Santa Catalina islands' as probable sources, but somehow that study became linked with the idea of larval supply from Mexico.

No other data set on annual recruitment patterns of subtropical reef fishes in both the SCB and Baja California are available to evaluate whether Cowen's (1985) finding is a recurrent and widespread phenomenon; however, the larval abundance time series presented here makes it unlikely. Episodic booms likely occur at less than an SCB-wide scale due to spatial and temporal stochasticity in larval supply and local environmental conditions, as suggested by the age structure data. 
Moser et al. (2001) suggested that the 1998 peak in Semicossyphus pulcher larvae, which occurred on the September cruise, may have stemmed from El Niñodriven poleward advection across the international border early that year. Flow in the SCB was intensely monitored over the course of the 1997 to 1999 El Niño/ La Niña event (Lynn \& Bograd 2003), allowing a test of the possibility that sheephead larvae were in the plankton during the flow-reversal event. Poleward flow originating from south of Punta Eugenia dominated the inshore surface layer (0 to $200 \mathrm{~m}$ ) of the SCB from April 1997 to February 1998, but returned to equatorward flow by April 1998 (see Fig. 9 in Lynn \& Bograd 2003). S. pulcher and Paralabrax spp. larvae do not appear until June (Moser et al. 2002). Based on the pelagic larval duration of these species (60 and $30 \mathrm{~d}$, respectively), it is unlikely that larvae would have been in the water column during April 1998 as eggs. In addition, although there was strong inshore poleward flow in the SCB in July 1998, it is unlikely to have originated from far to the south as Moser et al. (2001) implied; instead, it is more likely the result of the strengthening of the CC driving stronger cyclonic flow in the Southern California Eddy. Lynn \& Bograd (2003) reported that the strengthening of the inshore countercurrent in spring 1998 correlated with the CC strengthening and expanding shoreward (see their Fig. 10), the opposite response that the $\mathrm{CC}$ would have if the poleward flow resulted from a flow reversal from Mexico. Thus, it is more likely the peak in S. pulcher larvae in September 1998 was a locally produced phenomenon.

The California Undercurrent, a band of poleward flow below the CC, warrants mention as an alternate source of poleward transport. This current is centered at depths of 100 to $300 \mathrm{~m}$ at the continental slope (Lynn \& Simpson 1990) and this depth range is likely too deep for the larvae of Semicosyphus pulcher, Paralabrax spp., and many other shorefishes, which are found mostly in the surface and midwater (<100 m depth) (Waples 1986). However, the undercurrent occasionally shoals and could be responsible for some poleward transport. Nevertheless, genetic results discussed below suggest poleward transport is not important, at least for P. clathratus. The larvae of rockfishes and lobster are found deep enough to access the California undercurrent, so SCB populations of these species may have more reliance on Mexican sources than $P$. clathratus and S. pucher populations. However, preliminary microsatellite analysis of California spiny lobster Panulirus interruptus populations suggests there is genetic differentiation between sites in the SCB and central Baja (K. A. Selkoe \& T. Ben-Horin unpubl. data).

Paralabrax clathratus genetic structure is low but statistically significant, as is typical for marine fishes with planktonic larvae (Purcell et al. 2006); significant structure exists in both California and Mexico, and the spatial patterns are inconsistent with large influxes of larvae from Mexico. The finding of isolation by distance in northern Baja California fits with the linear currents along this stretch of the coast, and its statistical significance despite low $F_{\mathrm{ST}}$ values rules out panmixia or non-equilibrium conditions that would make the genetic results uninformative (Palumbi 2003, Purcell et al. 2006). Extrapolation of dispersal distance from the isolation by distance slope according to Palumbi (2003) would suggest an average dispersal distance of $80 \mathrm{~km}$, although there is high variance around such estimates. The even higher pairwise $F_{\mathrm{ST}}$ values in the lower SCB implies even smaller average dispersal distances and/or greater self-recruitment there. These high pairwise $F_{\mathrm{ST}}$ values in the SCB support the hypothesis that local production dominates. The fact that allele frequencies at several sites in the SCB sampled 3 to 14 yr apart are temporally stable (Selkoe et al. 2006) also implies that gene flow patterns are stable, instead of fluctuating with El Niño events. The absence of isolation by distance in the SCB fits with the complex, circuitous flow in the Southern California Eddy, as the circular flow of the eddy should decouple gene flow patterns from linear geographic distance. For instance, there is low genetic differentiation between sites in the Santa Barbara Channel and the lower SCB (Fig. 4b) that may be due to direct dispersal between these areas via the western edge of the Southern California Eddy, a feature only present in non-El Niño conditions.

The pattern of genetic structure for the Baja-SCB pairs also fits with the large-scale flow patterns present only in non-El Niño conditions. The highest genetic differentiation occurs between sites closest to the border (Fig. 4c), perhaps because the divergent flow at the Ensenada front serves as a dispersal boundary. The high genetic similarity of the site pairs at the largest distances was an unexpected result; however, it does not indicate the species is panmictic, nor does it negate the evidence for local production indicated by the other genetic data and the ecological data. In fact, the low values of genetic differentiation for the most distant pairs may indicate gene flow from the northern and western edges of the SCB to the central Baja California sites via long-distance equatorward transport on the CC. During normal summer conditions, the CC moves eastward and meanders continuously (Hickey 1998), potentially allowing larvae produced in the Santa Barbara Channel, the islands on the western edge of the $\mathrm{SCB}$, and north of Point Conception to be drawn into the equatorward flow, either by the action of turbulent diffusive processes or westward advection during flow anomalies. Some of these larvae may stay in the main 
equatorward flow of the CC until it impinges on the coast in central Baja California, at and just north of Punta Eugenia (Fig. 1a). Drifter studies demonstrate this route is possible in the timeframe of a 30 to $40 \mathrm{~d}$ larval period, as the CC flow becomes jet-like en route, reaching speeds of 25 to $50 \mathrm{~cm} \mathrm{~s}^{-1}$ (Bray et al. 1999, Sotka et al. 2004). Traveling with flotsam and mats of kelp, as has been shown for several species (Mitchell \& Hunter 1970), makes survival on this route more likely. Three other genetic studies of nearshore fishes along this coastline also show unusually high genetic similarity between samples in central Baja and the northern or western edges of the SCB, suggesting disjunct dispersal between the 2 areas (Girella nigricans, Terry et al. 2000; kelpfishes, Stepien \& Rosenblatt 1991; kelp bass, Grothues 1994). Although CalCOFI tows have rarely found larvae at the open water stations of the main CC flow, only a few successful larvae are required to homogenize allele frequencies, and the tows do not sample kelp rafts, which are the most likely mechanisms of transfer. The genetic signature of this disjunct equatorward dispersal on the CC differs from that of poleward transport on El Niño flow reversals because it produces highest genetic similarity between the edges of the range instead of within the center of the range (Fig. 4c). In addition, the genetic similarity of the Santa Barbara Channel sites with all other sites (while central Baja sites differ from most) fits with the distribution of their larvae to the southern SCB and central Baja California via the dominant southward flow of the CC. Although genetic structure is low overall, the level of international dispersal is likely small on ecological time scales and there is no indication that SCB populations are sustained by Mexican immigrants.

The analyses in this paper present several important implications for management of these species. In and of itself, the high interannual variability in recruitment is an important consideration for managing fished species. High recruitment fluctuations indicate that in many years few individuals spawn successfully, and perhaps successful reproduction is concentrated in one or a few locations (Larson \& Julian 1999). In order to avoid local extirpation during stretches of recruitment failure and promote more widespread reproductive success in favorable years, fisheries managers may want to preserve older, highly fecund individuals throughout the region as an insurance factor (Berkeley et al. 2004). Determining the spatial scale of variation in recruitment with large-scale, coordinated monitoring of recruitment throughout Baja California and the SCB would provide insight into the causes of high interannual stochasticity in recruitment: local factors, random chance, or large-scale climatic factors. The fact that recruitment strength and population density of many of SCB's reef fish species has been declining in recent decades makes the need to understand what produces a high recruitment year all the more urgent (Holbrook et al. 1997).

The age structure and genetic results for Paralabrax clathratus suggest that larval replenishment in the SCB is local and will be best served by focusing protection on SCB populations instead of counting on replenishment from the larger stocks in Mexico. The Marine Life Protection Act (MLPA) Initiative proposes establishing marine protected areas in California to sustain populations of marine flora and fauna. One strategy behind creating a network of marine reserves in this region is to protect key source populations that may supply larvae to areas outside of the reserves. Consequently, the current focus is ascertaining the exact patterns of connectivity for key species to determine the ideal reserve configuration to promote larval export (Sale et al. 2005). However, the high variation in pairwise $F_{\mathrm{ST}}$ values in the SCB suggest that there is high spatial variability in the scale of connectivity within the SCB, and the age structure data indicate high spatial variability in recruitment within the SCB (A. Vogel, C. Burrell, S. Edmands, D. Keifer unpubl.), implying that many reserve network configurations will have equivalent likelihoods of success. Moreover, as the sea temperature continues to warm in the coming century, or the frequency and intensity of El Niño events change, coastal population dynamics and connectivity may be altered dramatically, warranting an adaptive approach to management.

Acknowledgments. Thanks to C. White, J. E. Caselle, and B. S. Halpern for editorial comments. This work was supported by National Science Foundation (NSF) Dissertation Enhancement Grant number 0402589 (K.A.S.), an NSF graduate fellowship (K.A.S.), a Coastal Environmental Quality Initiative Collaborative Grant from the UC Marine Council (K.A.S. \& S.D.G.), the Andrew W. Mellon Foundation (S.D.G.), NMSP MOA\#2005-008/66882 (K.A.S.). This is contribution number 275 from PISCO, the Partnership for Interdisciplinary Study of Coastal Oceans funded primarily by the David and Lucile Packard and Gordon and Betty Moore Foundations (K.A.S. \& S.D.G.).

\section{LITERATURE CITED}

Allen LG, Hovey TM, Love MS, Smith JTW (1995) The life history of the spotted sand bass (Paralabrax maculatofasciatus) within the Southern California Bight. Cal Coop Fish Invest Rep 36:193-203

Belkhir K, Borsa P, Goudet J, Chikhi L, Bonhomme F (1998) GENETIX, logiciel sous Windows pour la genetique des populations. Laboratoire Genome et Populations, Montpellier, France

Berkeley SA, Hixon MA, Larson RJ, Love MS (2004) Fisheries sustainability via protection of age structure and spatial distribution of fish populations. Fisheries 29:23-32

Bray NA, Keyes A, Morawitz WML (1999) The California Current system in the Southern California Bight and the Santa Barbara Channel. J Geophys Res 104:7695-7714 
Carr MH (1994) Effects of macroalgal dynamics on recruitment of a temperate reef fish. Ecology 75:1320-1333

Chelton DB (1981) Interannual variability of the California Current: physical factors. Calif Coop Ocean Fish Invest Rep 22:34-48

Cowen RK (1985) Large scale pattern of recruitment by the labrid, Semicossyphus pulcher: causes and implications. J Mar Res 43:719-742

Durazo R, Baumgartner TR (2002) Evolution of oceanographic conditions off Baja California: 1997-1999. Progr Oceanogr $54: 7-31$

Grothues TM (1994) An investigation into the genetic population structure and larval dispersal patterns of the kelp bass, Paralabrax clathratus. MSc thesis, California State University, Northridge

Haury LR, Venrick EL, Fey CL, McGowan JA, Niiler PP (1993) The Ensenada front: July 1985. Calif Coop Ocean Fish Invest Rep 34:69-88

Hedrick PW (2005) A standardized genetic differentiation measure. Evolution 59:1633-1638

Hickey BM (1998) Coastal oceanography of western North America from the tip of Baja to Vancouver Island. In: Robinson AR, Brink KH (eds) The sea: the global coastal ocean: regional studies and synthesis, Vol 11. John Wiley \& Sons, New York, p 345-393

Holbrook SJ, Schmitt RJ, Stephens JS (1997) Changes in an assemblage of temperate reef fishes associated with a climate shift. Ecol Appl 7:1299-1310

Johnson MW (1960) The offshore drift of larvae of the California spiny lobster Panulirus interruptus. Calif Coop Ocean Fish Invest Rep 7:147-161

Kalinowski ST (2002) Evolutionary and statistical properties of three genetic distances. Mol Ecol 11:1263-1273

Larson RJ, Julian RM (1999) Spatial and temporal genetic patchiness in marine populations and their implications for fisheries management. Calif Coop Ocean Fish Invest Rep 40:94-99

Lenarz WH, Ventresca DA, Graham WM, Schwing FB, Chavez F (1995) Explorations of El Niño events and associated biological population dynamics off Central California. Calif Coop Ocean Fish Invest Rep 36:106-119

Love MS, Yoklavich M, Thorsteinson L (2002) Rockfishes of the northeast Pacific. University of California Press, Berkeley, CA

Lynn RJ, Bograd SJ (2003) Dynamic evolution of the 1997-1999 El Niño-La Niña cycle in the southern California Current System. Progr Oceanogr 54:59-75

Lynn RJ, Simpson JJ (1990) The flow of the undercurrent over the continental borderland off Southern California. J Geophys Res 95:12995-13008

McGowen GE (1993) Coastal ichthyoplankton assemblages, with emphasis on the Southern California Bight. Bull Mar Sci 53:692-722

Methot R, Jagielo T, Heppell S (2004) Panel report: California sheephead stock assessment. California Department of Fish and Game, Sacramento, CA. Available at: www.dfg.ca.gov/marine/sheephead2004/pdfs/report.pdf

Mitchell CT, Hunter JR (1970) Fishes associated with drifting kelp, Macrocystis pyrifera, off the coast of southern California and northern Baja California. Calif Fish Game 56:288-297

Moser HG, Charter RL, Watson W, Ambrose DA and 5 others (2001) The CalCOFI ichthyoplankton time series: potential contributions to the management of rocky-shore fishes. Calif Coop Ocean Fish Invest Rep 42:112-128

Moser HG, Charter RL, Smith PE, Ambrose DA, Watson W, Charter SR, Sandknop EM (2002) Distributional atlas of fish larvae and eggs from Manta (surface) samples collected on CalCOFI surveys from 1977 to 2000. Calif Coop Ocean Fish Invest Atlas 35

Oda DL, Lavenberg RJ, Rounds JM (1993) Reproductive biology of 3 California species of Paralabrax (Pisces, Serranidae). Calif Coop Ocean Fish Invest Rep 34:122-132

Palumbi SR (2003) Population genetics, demographic connectivity, and the design of marine reserves. Ecol Appl 13:S146-S158

Perez-Brunius P, Lopez M, Pineda J (2006) Hydrographic conditions near the coast of northwestern Baja California: 1997-2004. Cont Shelf Res 26:885-901

Pondella DJ, Stephens JS (1994) Factors affecting the abundance of juvenile fish species on a temperate artificial reef. Bull Mar Sci 55:1216-1223

Pringle JD (1986) California spiny lobster (Panulirus interruptus) larval retention and recruitment: a review and synthesis. Can J Fish Aquat Sci 43:2142-2152

Purcell JFH, Cowen RK, Hughes CR, Williams DA (2006) Weak genetic structure indicates strong dispersal limits: a tale of two coral reef fish. Proc R Soc B 273:1483-1490

Rosales-Casian JA, Gonzalez-Camacho JR (2003) Abundance and importance of fish species from the artisinal fishery on the Pacific coast of Northern Baja California. Bull South Calif Acad Sci 102:51-65

Rousset F (1997) Genetic differentiation and estimation of gene flow from F-statistics under isolation by distance. Genetics 145:1219-1228

Rousset F (2004) Genetic structure and selection in subdivided populations. Princeton University Press, Princeton

Sale PF, Cowen RK, Danilowicz BS, Jones GP and 7 others (2005) Critical science gaps impede use of no-take fishery reserves. Trends Ecol Evol 20:74-77

Selkoe KA, Aftab BT, Vogel A (2005) Eight polymorphic microsatellite markers for kelp bass, Paralabax clathratus, amplified in three multiplex PCR sets. Mol Ecol Notes 5:127-129

Selkoe KA, Gaines SD, Caselle JE, Warner RR (2006) Current shifts and kin aggregation explain genetic patchiness in fish recruits. Ecology 87:3082-3094

Smith CL, Young PH (1966) Gonad structure and the reproductive cycle of the kelp bass, Paralabrax clathratus (Girard), with comments on the relationships of the serranid genus Paralabrax. Calif Fish Game 52:283-292

Sotka EE, Wares JP, Barth JA, Grosberg RK, Palumbi SR (2004) Strong genetic clines and geographical variation in gene flow in the rocky intertidal barnacle Balanus glandula. Mol Ecol 13:2143-2156

Stephens JS Jr, Pondella DJ II (2002) Larval productivity of a mature artificial reef: the ichthyoplankton of King Harbor, California, 1974-1997. ICES J Mar Sci 59:S51-58

Stepien CA, Rosenblatt RH (1991) Patterns of gene flow and genetic divergence in the Northeastern Pacific Clinidae (Teleostei: Blennioidei), based on allozyme and morphological data. Copeia 4:873-896

Terry A, Bucciarelli G, Bernardi G (2000) Restricted gene flow and incipient speciation in disjunct Pacific Ocean and Sea of Cortez populations of a reef fish species, Girella nigricans. Evolution 54:652-659

Thomson CJ, Crooke SJ (1991) Results of the Southern California sportfish economic survey. NOAA Tech Mem NMFS. NOAA-TM-NMFS-SWFC-164, La Jolla, CA

Tolimieri N, Levin PS (2005) The roles of fishing and climate in the population dynamics of bocaccio rockfish. Ecol Appl 15:458-468

Ventresca DA, Parrish RH, Houk JL, Gingras ML, Short SD, Crane NL (1995) El Niño effects on the somatic and repro- 
ductive condition of blue rockfish, Sebastes mystinus. Calif Coop Ocean Fish Invest Rep 36:167-174

Waples RS (1986) A multispecies approach to the analysis of gene flow in marine shore fishes. University of California, San Diego, CA

Waples RS, Rosenblatt RH (1987) Patterns of larval drift in Southern California marine shore fishes inferred from allozyme data. Fish Bull 85:1-11

Watson W, Charter RL, Moser HG, Vetter RD and 6 others (1999) Fine-scale distributions of planktonic fish eggs in the vicinities of Big Sycamore Canyon and Vandenberg

Editorial responsibility: Steven Morgan (Contributing Editor), Bodega Bay, California, USA
Ecological Reserves, and Anacapa and San Miguel Islands, California. Calif Coop Ocean Fish Invest Rep 40:128-153 Watson W, Charter RL, Moser G, Ambrose DA, Charter SR, Sandknop EM, Robertson LL, Lynn EA (2002) Distributions of planktonic fish eggs and larvae off two state ecological reserves in the Santa Barbara Channel vicinity and two nearby islands in the Channnel Islands National Marine Sanctuary, California. Calif Coop Ocean Fish Invest Rep 43:141-154

Weir BS, Cockerham CC (1984) Estimating F-statistics for the analysis of population structure. Evolution 38:1358-1370

Submitted: September 22, 2006; Accepted: July 12, 2007

Proofs received from author(s): November 19, 2007 